\title{
Ethical values adaptation in international B2B relationships: case of Russian immigrant entrepreneurs in Finland
}

\author{
Olga Dziubaniuk and Maria Ivanova-Gongne \\ School of Business and Economics, Åbo Akademi University, Turku, Finland
}

\begin{abstract}
Purpose - This study aims to explore how Russian-origin immigrant entrepreneurs manage to adapt their business-to-business (B2B) relationship management practices and moral concerns to the business ethics of their country of origin and of the host country via the prism of ethical relativism. By focusing on the ethical values of immigrant entrepreneurs in a business relationship context, the study aims to extend the currently limited understanding of these issues in the B2B marketing field.

Design/methodology/approach - A qualitative approach is applied to provide findings from eight in-depth interviews with first-generation Russian entrepreneurs living and doing business in Finland. A narrative approach to the data analysis is used, in particular by applying a thematic analysis of the collected interviews because of the focus on the personal experiences of the interviewees.

Findings - The results illustrate how the immigrant entrepreneurs adapt to ethical values and norms in Russia and Finland and how they enact those values in B2B relationship management in the countries. Immigrant entrepreneurs share several national and ethical backgrounds, which may influence their interaction in international markets, helping them adapt to country-specific business ethics.

Practical implications - The results imply that managers should acquire knowledge on ethical norms at the global level and at the national level, where they aim to expand their business. Productive business relationships involve the premises of honesty, transparency, fairness toward business partners and minimizing opportunism. However, business relations between developed and emerging markets may demand relativism when addressing ethical behavior.

Originality/value - This is one of the few studies that explore the ethical values of immigrant entrepreneurs in the context of international business relationships. The study contributes to the limited literature on ethics in the fields of B2B marketing and immigrant entrepreneurship. The authors encourage further research on ethical values adoption by immigrant entrepreneurs, which is an essential topic in times of increased workforce immigration.
\end{abstract}

Keywords Russia, Finland, Business ethics, Immigrant entrepreneurs, Relativism, Ethical adaptation

Paper type Research paper

\section{Introduction}

As an essential part of any type of business endeavor, business ethics has received more attention over the past several decades because of increased globalization and heightened stakeholder attention being paid to any of a company's or manager's misdemeanors (Morrison, 2015). In the current article, we view business ethics as developed norms and values in business relationships. These norms place the morals of individuals/ managers at the core of business interaction and can lead to fruitful business relationships (Boatright, 2000; Melé, 2009). International business organizations and entrepreneurs attempt to adopt universal "rights and wrongs" in the managerial practices of international business, but they have to consider cultural and social differences in the global business context (Warren, 2011). Deviances in business behavior arise not from the differences in managers' moral values but rather from the

The current issue and full text archive of this journal is available on Emerald Insight at: https://www.emerald.com/insight/0885-8624.htm

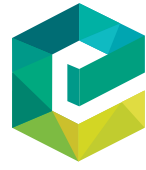

Journal of Business \& Industrial Marketing 36/13 (2021) 91-104

Emerald Publishing Limited [ISSN 0885-8624]

[DOI 10.1108/JBIM-06-2020-0287] need to apply those values in different countries or markets, so the role of ethical relativism (McDonald, 2010) should be considered in managerial decision-making across borders. Ethical relativism asserts that the business ethics and moral concerns of one country may be disapproved of in another country, due to differences in the social context, culture and historical development (Dion, 2010). Given that firms often span borders and national boundaries, it is especially vital to consider the issue of ethical relativism when conducting business relationships in the current international business environment. Despite business ethics being embedded within the business interaction process (Lindfelt and Törnroos, 2006) and playing a significant role in the development of business

(C) Olga Dziubaniuk and Maria Ivanova-Gongne. Published by Emerald Publishing Limited. This article is published under the Creative Commons Attribution (CC BY 4.0) licence. Anyone may reproduce, distribute, translate and create derivative works of this article (for both commercial \& non-commercial purposes), subject to full attribution to the original publication and authors. The full terms of this licence may be seen at http://creativecommons.org/licences/by/4.0/legalcode

Received 19 June 2020

Revised 28 December 2020

21 February 2021

Accepted 21 February 2021 
relationships, managers' ethical values are under-researched within the scope of the business-to-business (B2B) marketing literature (Halinen and Jokela, 2016). This is especially relevant considering that ethical relativism is also crucial when looking at business interactions led by immigrant entrepreneurs, who have to deal with partners from both host and home countries and adapt their behavior accordingly. Although the research on immigrant entrepreneurs has touched upon interactions with ethnic communities, as well as the cultural and social embeddedness of entrepreneurs, issues such as the ethical values of immigrant entrepreneurs have rarely been covered (for rare exceptions, Azmat, 2010; Fatoki, 2015).

Individuals working within the context of another business culture and its ethical values may well pursue native moral principles and the ethical behaviors that could influence their professional life and entrepreneurial skills (Bailey and Spicer, 2007). Thus, we focus on first-generation immigrants' adaptation to ethical values in the host market business context as opposed to the conventional values arising from their individual backgrounds. In particular, the current study explores how first-generation, Russian-origin immigrants in Finland adapt to the ethical values that are dominant in Russia and Finland when managing international business relationships. Individuals of Russian origin form one of the largest immigrant groups in Finland (Statistics Finland, 2018) and are among the top nationalities to engage in immigrant entrepreneurship in Finland (Fornaro, 2018). Furthermore, past research has widely recognized the uniqueness of doing business in Russia because of differing views on, for instance, corruption, bribery and other ethical issues (McCarthy and Puffer, 2008; Karhunen et al., 2018). Although immigrants may act differently in the host market and adapt to local ethical values, they are still keener to adopt ethical relativism when dealing with ethically challenging situations, as they may have a deeper understanding of the cultural and social values of the foreign markets (Hrenyk et al., 2016). Thereby, focusing on Russian immigrants in Finland who conduct business both with local Finnish partners and Russian partners in Russia may provide fruitful results both theoretically and empirically.

The current research aims to answer the following question: how do the ethical values of first-generation immigrants vary according to their host market and international business context within which they operate? In terms of the host market, we look particularly at how immigrants apply ethical values in the local Finnish business environment and do not consider ethnic enclaves. By the international business context, we imply that the immigrant entrepreneurs are holding interactions with partners outside Finland. To achieve our aims, data was collected via in-depth interviewing of Russian-origin immigrant entrepreneurs who have been managing international business relationships both with Finnish and Russian partners. We applied a narrative analysis (Boje, 2001) approach to reveal how those entrepreneurs understand and adapt to the (un) ethical business practices of both countries. The major criterion for selecting respondents was their experience of managing business relationships with partners in Russia and Finland.

The research paper delivers several important core contributions. In particular, it is one of the rare studies to focus on immigrant entrepreneurs' ethical values (Fatoki, 2015) and their operationalization in international business relationships.
We also contribute to the otherwise limited literature on immigrant entrepreneurs in the business marketing and business relationships field in particular (Milanesi et al., 2016; Zolfagharian and Iyer, 2020; Gurău et al., 2020). Furthermore, the present study extends the understanding of ethical relativism as applied in the context of international B2B relationships, here by focusing on the individual level.

The rest of the paper is structured as follows: First, we deliver a review of the literature on business ethics from the international $\mathrm{B} 2 \mathrm{~B}$ relationships perspective, on relativism and on the principles of ethical adaptation. Second, the socioethical contexts of Russia and Finland are discussed. Third, the research methods section presents detailed processes of the data collection and analysis. The results section describes the experiences of the immigrant entrepreneurs in managing B2B relationships in both countries, emphasizing their ethical concerns. Finally, the discussion and conclusion sections clarify the challenges of ethical adaptation.

\section{Ethical relativism in the context of international business-to-business relationships}

International relationship management involves the interaction of companies but, more importantly, of their managers (actors). As any human being, managers possess morals and ethical values that may affect the B2B interaction process. Ethical values are initially embedded in the social relationships formed among the actors (Halinen and Törnroos, 1998; Lindfelt and Törnroos, 2006), as their interaction involves active manager participation and moral contribution into productive relationship management. The moral values and norms - or standards of business behavior - developed within the context of relationships represent as business ethics and are essential for business relationships (Melé, 2009). Documented and informal ethical codes emerge from the common history of companies' interactions. As business relationships are dynamic and tend to evolve over time (Holmlund and Törnroos, 1997), ethics also continue to develop within relationships, forcing actors to adapt accordingly. Any business relationship can develop specific ethical norms that typical only to specific social interactions. However, within international markets, it may be challenging to develop an ethical code that would be favorable for all actors, as representatives of different countries follow the ethical values and morals dominant in their country of origin.

International business organizations frequently face the dilemma of which moral obligations to accept: those of the host or home country. Thus, companies from developed markets tend to implement minimal moral obligations as being acceptable in the host markets (Donaldson, 1989; Iyer, 2001). However, business representatives of developed and emerging markets cannot avoid confronting international ethical principles of business conduct. Aligning ethical behavior in businesses is actively promoted by the United Nations via, for instance, its Global Compact initiative. Ethical principles such as fairness, honesty, trust and not cheating can be considered universal and preferable to follow for all international companies (Asgary and Mitschow, 2002). Still, national business ethics should also be taken into account. For instance, the fair treatment of employees, which is significant in the European business context (Cory, 2005), cannot always be 
executed in emerging markets. In general, it is challenging for companies to enact universal global ethical standards, as they can be forced to accept local norms, values and other ethical standards with a degree of relativism.

Everyone has their own set of moral principles, but they have to follow (though not necessarily) commonly accepted ethical norms. Although the morality of individuals and their ethics of behavior are interrelated, the meaning of these concepts differs. Morality is an abstract concept that is defined as the obligations that individuals have to other members of society in terms of justice and a pattern of thought guiding a person's daily behavior (Brinkmann, 2002). Contrarily, ethics represents a rather idealistic way of approaching reality, one that does not reflect reality as it is but how it ought to be (Grcic", 1989). Ethics assumes convictions regarding the values and norms that a person ought to follow and that are changeable depending on the circumstances (Lukes, 2008). Managers may attempt to pursue the ethical business behavior of their home country, but their attempts may be neglected in countries with ethical standards rooted in other traditional moralities, cultures and values (Javalgi and Russell, 2018).

Thus, the ethicality of business behavior is hardly universal, and ethics or morality are not absolute; instead, they are a reflection of a certain society and its traditions. It is significant to consider all circumstances where this morality and ethicality of behavior originate and develop, for instance, the environment, dominant politics, history, the economic system and social structure (Lukes, 2008). For instance, a concept such as guanxi in China plays a crucial role in ethical concerns. Guanxi implies a continued exchange of favors within (interpersonal) relationships (Dobrucali, 2019) and "reciprocal obligations to respond to a request for assistance" (Michailova and Worm, 2003, p. 510) based on family connections (Jansson et al., 2007). Although Westerners regard this concept as simple corruption, for Chinese managers, a more interpersonal approach is inherent to their Confucian ethical principles (Lovett et al., 1999). Thus, Lovett et al. (1999, p. 234) speak of ethical relativism (De George, 1993), an approach that emphasizes the idea that "there are no universal ethical standards" and "that guanxi is based on Eastern principles, and can be as ethical as any Western system" in a particular society.

Ethical relativism implies a multiplicity of moral beliefs, as the moral principles and cultural and contextual backgrounds are relative to individuals. Thus, a person makes sense of beliefs and values according to the social context within which they live, adopting specific behavioral patterns (McDonald, 2010; Oumlil and Balloun, 2017). A social construct such as corruption can be legitimate in one country but unacceptable in another from both legal and moral perspectives (Dion, 2010). However, the realities of foreign markets may pressure managers to disregard their usual ethical principles of business behavior and follow the local rules (Thomas and Peterson, 2017). The importance of ethical relativism should not be underestimated. Misunderstandings or neglecting local ethics in business interactions may lead to unpredictable outcomes. For instance, ethical blindness is a concept representing managerial unintentional or irrational unethical behavior (Palazzo et al., 2012), meaning that unethical behavior can be exhibited due to a lack of knowledge. However, ignorance does not imply the exemption of responsibility. Therefore, international companies can benefit from employees possessing knowledge of country-specific business ethics.

\section{Immigrant entrepreneurs' ethical values and ethical adaptation in business relationships}

The emigration of people from emerging to developed countries has resulted in a number of immigrant managers and entrepreneurs skilled in managing relationships in both country types (Devitt, 2011; Nazareno et al., 2019). These individuals may be particularly skillful in terms of ethical relativism, as they may be better at evaluating how ethical a decision is by considering differences in the legal, political and cultural systems (Thomas and Peterson, 2017). Immigrant entrepreneurs are potentially multicultural individuals who because of their background, tend to approach (un)ethical situations with greater relativism compared with "monoculturals," as they can evaluate situations from different perspectives (Hrenyk et al., 2016). In addition, first-generation immigrant entrepreneurs are more prone to be influenced by their home country's contextual factors than second-generation individuals, who are more adapted to their country of residence (Azmat, 2010). Thus, immigrants can follow the prevailing ethical values of their home country and frequently, though not always, also accept the norms of the community where they reside (host country). Norms and values are significant factors in terms of integrating with the host country's society (Lukes, 2008). However, following ethical relativism principles can lead to certain challenges, as there may be discrepancies between the ethical values of the immigrant's country of origin and those of their country of residence. Thereby, immigrant entrepreneurs may need to adapt their ethical values depending on the business partners with whom they interact and the context of the business relationship.

From the individual perspective, adaptation means adjustment of the behavioral pattern of a business actor to correspond to the expectations and demands of another business actor (Brennan et al., 2003). Adaptation, according to Brennan and Turnbull (1996), among other types of adaptation (political, decision-making, evolutionary and investment), is a socialization process: individuals determine the gaps in interaction behavior and attempt to adjust their own ethical norms of behavior closer to the norms of the other party. The level of adaptation in business relationships depends on the number of differences between the actors (Gadde and Håkansson, 1993). Therefore, the greater the difference between actors, including the discrepancies in their ethical values, the more they have to adapt to each other. Naturally, adaptation at the interpersonal level demands adjustments not only to the cultural settings but also to the dominant ethics in the host business environment. This social adaptation facilitates business ethics development, which can, for instance, influence commitment and loyalty development in business relationships (Hagberg-Andersson, 2006). Thus, the personal moral values of managers should also be counted in adaptation for the sake of business relationships.

The ethical and less ethical constructs that can be involved in international B2B interactions are summarized in Table 1. Their development and employment originate in a country's 
Table 1 Ethical constructs of international B2B relationships

\begin{tabular}{|c|c|c|}
\hline Relationships specifics & Ethical constructs & Theoretical sources \\
\hline Individual moral values & $\begin{array}{l}\text { Honesty } \\
\text { Fairness } \\
\text { Loyalty } \\
\text { Personal vs professional qualities }\end{array}$ & $\begin{array}{l}\text { Puffer and McCarthy (2011), Grennes (2011), Ledeneva (2009), } \\
\text { Holzlehner (2007), Ivanova and Torkkeli (2013), Velasquez, (2012), } \\
\text { Fiske (2005), Anderson and Jap (2005), Grayson (2007) }\end{array}$ \\
\hline Business ethics in partnerships & $\begin{array}{l}\text { Opportunism vs pursing the } \\
\text { interests of a partnership network }\end{array}$ & Hawkins et al. (2013), Miller et al. (2020), Handley and Angst (2015) \\
\hline Developing trust & $\begin{array}{l}\text { Trust } \\
\text { Transparency } \\
\text { Commitment to business partners }\end{array}$ & $\begin{array}{l}\text { Panapanaan et al. (2003), Brown et al. (2019), Arnott (2007), Myskja } \\
\text { (2008), Gounaris (2005), Akkermans et al. (2004), Mora Cortez and } \\
\text { Johnston (2019) }\end{array}$ \\
\hline Power and hierarchy & $\begin{array}{l}\text { Collective responsibility vs } \\
\text { individual responsibility } \\
\text { Equity in business decision-making } \\
\text { Control of business processes }\end{array}$ & $\begin{array}{l}\text { Asgary and Mitschow (2002), Vredenburgh and Brender (1998), Rozov } \\
\text { (2011) }\end{array}$ \\
\hline Attitude and respect & $\begin{array}{l}\text { Respect toward the involved } \\
\text { business partners vs disrespect }\end{array}$ & $\begin{array}{l}\text { Shaw (1994), Trompenaars and Hampden-Turner (2011), Edvardsson } \\
\text { et al. (2014) }\end{array}$ \\
\hline
\end{tabular}

historical development and the social environment typical of that country. For instance, individual morals such as honesty and fairness may be prevalent in Western markets, where the business environment is also regulated and the law has power (Asgary and Mitschow, 2002; Grennes, 2011). Less institutionally regulated markets force entrepreneurs to practice conspiracy in their business activities, relying on social relations for business benefits (Puffer and McCarthy, 2011). For example, in the Russian context, the importance of social ties is often rooted in blat, meaning personal ties to obtain benefits and, hence, bypassing official procedures (Ledeneva, 2009). Blat is still common in Russian markets and may affect international interactions. Although blat is conventionally related to informal institutions, it is also applicable to business relationship management (Voldnes et al., 2012). Another term applied in Russia's turbulent marketplace is "roof," which, in this context, means the patronage of a business organization by criminals in exchange for payment (Holzlehner, 2007). "Roof" also demands the loyalty of the client to the organized crime actors, giving loyalty a negative connotation. In terms of positive loyalty expressed to a business partner, loyalty at the individual level can be developed during long-term business interactions or friendships (Ivanova and Torkkeli, 2013). However, moving from professional relations to forced friendships can be associated with familiarity. In this case, the term familiarity is related to inappropriate ethical behavior in business relationships, where a participant may experience engagement in the social relationships forced by other participants. Thus, familiarity can be a negative side of business relationships and friendships that are too close (Anderson and Jap, 2005; Grayson, 2007).

Professional and individual qualities frequently motivate individuals to engage in business relationships. However, international business partners may be evaluated with some prejudgment that is frequently based on stereotypes and expectations of specific (un)ethical behavior from other social groups. Prejudgment is a natural human behavior that implies the categorization of people into us and them (Fiske, 2005). Prejudgment forces people to evaluate the professional capabilities of other groups of people based on the dominant stereotypes, many of which may qualify as unethical business behavior (Velasquez, 2012).

Assessing the interest of business partners may be significant in achieving mutual business goals. However, business partners in pursuit of a business opportunity or self-interest may abandon commitment and exit a business relationship, which may be regarded as opportunistic behavior (Hawkins et al., 2013). For instance, distrust in business partners and a lack of transparency in business relationships provoke a search for other opportunities (Miller et al., 2020). Opportunistic behavior may originate in the individual's cultural background. Companies may resort to contractual agreements to reduce opportunistic behavior. However, research on collectivist and individualist countries indicates that relying on contractual agreements is not enough in collectivistic countries; other methods of reducing opportunism should be implemented, such as social networking (Handley and Angst, 2015).

Transparency in business relationships is important; for instance, in the Nordic business environment (Panapanaan et al., 2003), transparency is appreciated by business partners and helps to develop trusting relationships (Akkermans et al., 2004; Mora Cortez and Johnston, 2019). Trust and commitment are known concerns in B2B research (van Zeeland-van der Holst and Henseler, 2018; Brown et al., 2019). In the current study, trust is regarded as belief in the fulfillment of promises made by a business partner in risky situations (Arnott, 2007). Trust employment can be useful in cases where business actions cannot be formally verified or documented (Myskja, 2008), which may be the case when dealing with emerging markets. Commitment can be understood as a motivation to engage in business relationships (Gounaris, 2005), and in some cases, along with trust, it can provide economic and noneconomic satisfaction in business relationships (Høgevold et al., 2020).

Power and hierarchy can expose the distribution of managerial power and influence in business relationships and inside a business organization (Vredenburgh and Brender, 1998). This issue raises the question of who is responsible and for what in a business organization. In some, responsibilities may be bestowed only on the higher managerial staff (or just 
one person), leading to the low participation of other employees in decision-making. For instance, responsibility avoidance by Russian lower-level managers originates from the Soviet central planning system and the abolition of private property (Rozov, 2011), where a person was considered a part of the bigger mechanism of production rather than an individual. This attitude toward responsibility may also influence the company's external partnerships as partnerships frequently occur at different levels and not only among key managerial staff. Western managers are keener to account for the opinion of their business partners in decision-making if the matter concerns external relationships (Asgary and Mitschow, 2002).

A positive attitude in a business partner can be expressed, for instance, via punctuality and respect for other people's time as significant indicators of business ethics (Shaw, 1994). By being punctual, an entrepreneur can express their respect toward business partners and to the firm. However, time is a social construct and can be understood differently in different countries or cultures (Trompenaars and Hampden-Turner, 2011). Thus, unintentional disrespect may be demonstrated if the representatives of different cultures have to collaborate. Respect is embedded in social interaction and is similar to the trust that needs to be developed or earned in business relationships (Edvardsson et al., 2014).

As a consequence of improved abilities to adapt to the specifics of the host country (Chen et al., 2008) and being able to apply different ethical principles, immigrant entrepreneurs may be more competent in handling business relationships across the different ethical values of the business contexts in which they are involved.

\section{Socio-ethical background}

\subsection{Finland}

The geographical proximity of Finland to European business centers and the country's interactions with international businesses has played a significant role in the adoption of commonly accepted European ethical values in business conduct. Finland can be termed a corporatist country, where agreements are achieved through negotiations between the government, labor unions, employer organizations and other parties of interest (Korhonen and Seppälä, 2005). Conventionally, Finnish companies are inclined toward cooperation and forming business networks rather than pursuing aggressive competition (Strand et al., 2015). Ethical values such as transparency and trust are emphasized as crucial and are conventionally specific to Northern European morals in business conduct (Panapanaan et al., 2003). Previous research indicates that the most important ethical values for Finnish managers are honesty, keeping promises, power-sharing, respect for others, fairness, loyalty and the pursuit of excellence (Kujala, 2004; Grennes, 2011). Although the government supervises the legal side of business activities in Finland, Finnish society frequently pays attention to the ethical business behavior of companies abroad, especially in developing countries. Among the highest concerns are human rights violations, and labor standards. The ethical treatment of employees seems to be one major ethical concern as well (Korhonen and Seppälä, 2005).
In general, the Finnish business environment is quite favorable for business development, as the country has a low level of corruption, and companies are frequently positioned as "business in society" (responsibilities of business to society) rather than separated from it (Siltaoja and Onkila, 2013). This embeddedness of business in society is linked to the premises of implicit ethical business conduct that is common in Finland and other Nordic countries.

\subsection{Russia}

Russia's socio-historical background has played a crucial role in the development of business ethics in the country. The Soviets' abolition of private property and competition, its collectivism and government ownership of the means of production (Sidorov et al., 2000; Rozov, 2011) made it hard for entrepreneurs to accept free-market principles. After the collapse of the Soviet Union in 1991, inexperienced entrepreneurs had to develop their personal understanding of business processes in a market economy. The dominant traits of business ethics in modern Russia are grounded in interpersonal connections, loyalty to higher managerial staff, the hierarchy of power, interpersonal networking and mutual exchange of favors to obtain personal benefits bypassing legal institutions (McCarthy and Puffer, 2002; Lewis, 2006; Ivanova-Gongne and Torkkeli, 2018). The concept of blat became an important aspect of business and social relationships between individuals in Russia; this term stands for informal relationships used to obtain benefits (frequently nonmonetary, e.g. favors) among involved actors (Ledeneva, 2009). This form of the social network was a safe area during major transitions in markets and economies (Jansson, 2007). Currently, the term has obtained the general meaning of using interpersonal relationships to access various benefits, hence circumventing legal regulations (Michailova and Worm, 2003). Blat is not free from moral judgment, but in the Russian business context, it may be necessary to access services if the legal system is not efficient in supporting related business activities.

The rise of entrepreneurship in Russia has led to a shift from a collectivist ideology to individualism as a moral property. Thus, people started to care more about their individual, professional, social and financial possibilities (Apressyan, 1997). However, the adoption of Western business values in the Russian environment appeared to be a slow process, especially in the companies supported by the government. Small businesses are allegedly keener to accept Western individualistic values. Modern business managers in Russia respect leadership, status and risk-taking but are slower to adapt to market and technological changes (Hisrich et al., 2003). Russian entrepreneurs rely morally and financially on a group of individuals with whom they interact, which makes them more disposed to networking and developing business relationships (Beekun et al., 2003).

\section{Method}

We conducted eight face-to-face in-depth interviews from June to December 2018 with Russian-origin immigrant entrepreneurs who currently live and have experience of acting as entrepreneurs in Finland (Table 2). Interviewing as a 
Table 2 Outline of the research participants

\begin{tabular}{|c|c|c|c|c|}
\hline $\begin{array}{l}\text { Research } \\
\text { participants }\end{array}$ & Entrepreneurial expertize & Residence in Finland (years) & $\begin{array}{l}\text { Experience of } \\
\text { entrepreneurship } \\
\text { in Finland (years) }\end{array}$ & $\begin{array}{c}\text { Experience of entrepreneurship in } \\
\text { Russia/working with Russian } \\
\text { business partners (years) }\end{array}$ \\
\hline 1 & Business consulting & 22 & 8 & 8 \\
\hline 2 & High-tech industry & 14 & 3 & 3 \\
\hline 3 & Reseller & 9 & 3 & 2 \\
\hline 4 & Reseller & 12 & 12 & More than 12 \\
\hline 5 & Retailer in the fashion industry & 5 & 3 & 5 \\
\hline 6 & Dental services & 2 & 2 & 2 \\
\hline 7 & IT services, consulting & 9 & 5 & 12 \\
\hline 8 & R\&D, medical devices & 9 & 4 & 7 \\
\hline
\end{tabular}

method of data collection was selected, as interviews help attain respondents' perceptions and understand the research subject (Weiss, 2008). The interviews were conducted in a semistructured manner following an interview guide with predefined topics covering issues such as the core principles of doing business in Russia and Finland, the consideration of personal principles when adapting to Russian or Finnish ethics and friendship and trust in business relationships. The respondents were, however, encouraged to share any other matters concerning their experiences of managing international B2B relationships with Russian and Finnish business partners. To avoid bias, the researchers attempted to take a less active role in guiding the discussion, which meant just introducing the topics and allowing the respondents to further construct their own interpretations with minimal interference from the researchers. The interviews were conducted in Russian because using an interviewee's native language is beneficial in terms of understanding the more subtle nuances of the stories and the emotional stance of the respondents (Welch and Piekkari, 2006). For privacy reasons, the respondents were not named but assigned a number based on the order in which the interviews were conducted.

The respondents were selected according to the following criteria, namely, country of origin being Russia, currently a resident in Finland, the experience of entrepreneurial activities or work in the B2B area in Finland and Russia and experience of managing $\mathrm{B} 2 \mathrm{~B}$ relationships with partners from both countries. Although there are many Russian-origin entrepreneur-residents in Finland, finding entrepreneurs conforming to these particular criteria was challenging, as most of the immigrant entrepreneurs contacted in our search had no experience of B2B interactions with partners from their country of origin. The interviewed entrepreneurs have managed or are still managing their own small company, two of which were one-person micro-enterprises (Respondents 1 and 7). They both provide consulting services and possess a vast amount of experience in social interactions with business partners in Finland and Russia. Respondents 3-6 have established businesses in Finland because of their rich experience of entrepreneurial activities in Russia prior to moving to Finland. Thus, they could provide an informed comparison of the business contexts of both countries. Most of the respondents had a good command of the Finnish language for everyday life situations; however, it was not sufficient for professional use in their business activities. Although this created some inconveniences in their local business operations, they managed to continue their business processes. Almost all the respondents represent different spheres of business, which creates qualitative diversity, and, thus, a more holistic understanding of business ethics specific to Russia and Finland (Kvale, 1996).

We applied a narrative approach to the data analysis (Makkonen et al., 2012) and used, in particular, a thematic analysis for analyzing the collected interviews (Boje, 2001) because of the focus on the actions, impressions and personal experiences of the interviewees. Further, a narrative approach was selected because it is hard to compare the content of the interviews due to the uniqueness of respondents' experiences as they were recalling past events, which is typical of a narrative methodology (Labov and Waletzky, 1967). The thematic analysis concerns the content of the narrative texts (Riessman, 2005), as the researchers are interested in what was said rather than how.

During the analysis, first, the narratives were read to obtain a general sense of the stories. The narratives were then re-read, and information related to specific themes was underlined. We focused the analysis on the key elements of the respondents' stories, namely, actors, focal events, context (local and international markets), activities and interaction (Elliott, 2005). We underlined the most important information on business partners, managerial challenges, (un)ethical business behaviors, the specifics of the context of the Finnish and Russian market, etc. As our research interest is in individual understandings of the phenomenon by the respondents (Boje, 2001), we combined their perspectives to follow the differences and similarities in their stories. The findings were grouped according to the main themes, namely, establishing a business in a host country; the ethical relativism approach in business relationships between Russia and Finland; general ethical values specifics in business relationships in both countries; and the learning process of the business ethics of both countries.

\section{Results}

\subsection{Establishing a business in a host country and partnering with Russians and Finns}

Although the respondents had various reasons to engage in entrepreneurial activity, the main motivation for most of them was limited employment opportunities in the job market. Two 
of the respondents moved to Finland because of they saw an opportunity to establish their own business in the country and attempted to fill a gap in the market with their business offerings:

\section{[. . . I I decided to come to Finland as a country of opportunity. (Respondent 6)}

The Finnish business environment was relatively unknown to the entrepreneurs, but they encountered almost no challenges in starting a business. Contrary to the Russian market, where bureaucracy can slow the initiation of a venture, the Finnish entrepreneurial environment is favorable to foreigners. Some respondents also used government support that is startup money or grants for business development. One of the respondents indicated that they felt they were almost being mentored by their Finnish business partners' advise on establishing a business:

One of the managers of a small company, who was interviewing me [for a job], said: I can see that you have good experience but I can't hire you. You would not be working for a small salary. However, if you set up a company, I'd be happy to work with you on a business-to-business basis. (Respondent 7)

The respondents had initiated business relationships with Russian partners primarily to access low-cost services or products imported for resale in Finland.

\subsection{Ethical relativism in business relationships}

The respondents claimed they strictly follow Finnish business regulations and act according to Western ethical principles in business, for instance, involving all related actors in decisionmaking and transparency, which is a distinctive characteristic of Western business ethics (Asgary and Mitschow, 2002; Panapanaan et al., 2003). The interviewees emphasized that honesty and transparency in $\mathrm{B} 2 \mathrm{~B}$ relationships are key to fruitful relationships, especially at the international level. However, they were aware that it is impossible to expect absolute honesty from business partners:

I didn't agree to work by those [unethical] principles we were supposed to work by [...] It mostly happens in export markets, where bribes and some deception are a tradition. (Respondent 1)

Despite acting mostly by Western principles, the respondents stressed that it is morally acceptable to use some level of corruption within international relationships management. This shows some degree of ethical relativism, as what can be regarded as corruption in one country may be a norm in another (Lovett et al., 1999). The respondents agreed that despite the corruption, doing business in Russia is easier because the market is less formal compared with Finland, and business operations are often based on interpersonal relationships. This may be due to the weak legitimacy of formal institutions in Russia and the crucial role of informal traditions such as blat (Puffer and McCarthy, 2011). Thus, Russian current and past formal and informal institutions make Russian entrepreneurs more creative and risk-taking (Banalieva et al., 2018). The exchange of favors (blat) is still morally acceptable in Russia, despite the current market economy and private business development in the country (Ledeneva, 2009). Although blat does not currently have criminal connotations, as in the Soviet era or the 1990s (Michailova and Worm, 2003), it still has left an imprint on the respondents' understanding of the ethicality of business relationships in Russia.
In Russia, gangsters can attack you and demand money. You have to pay someone so that nobody touches you and your business runs smoothly. (Respondent 3)

In Russia, I had to cooperate with everybody! Once, some people came to me with weapons[...] they offered "a roof" for my business. Nevertheless, we came to an agreement! (Respondent 5)

The term "roof" is applied to services for physical protection and business risk minimization that a client may request willingly or be forced to pay for (Holzlehner, 2007). However, another interviewee, Respondent 4, claimed this patronage role has nowadays shifted to governmental institutions.

The immigrant entrepreneurs' experience of ethics in the Finnish market context is not so violent, but they have also encountered some dishonesty from Finnish partners. One of the respondents reported a story of a Finnish business partner manipulating payments for their company services. The case had attracted the attention of the Finnish tax office, and the Russian entrepreneur was obliged to pay additional taxes and, eventually, to address the court. This business relationship was terminated and ended in a scandal. This finding contradicts the generally accepted view of honesty as a core value in Finnish society and business dealings (Grennes, 2011), contradicting the expectations of the Russian immigrant entrepreneur. According to the respondents, Finns may circumvent the law if they see an opportunity to, especially if they are dealing with foreigners. Other respondents also mentioned that Finns may act unethically with foreign actors who are unfamiliar with Finnish statutes or have limited language skills to understand contract details. Nevertheless, the respondents still emphasized that conflict situations are more common in Russian than in Finnish partnerships:

There [in Russia] they love conflicts! It's a sport for them! Sense of their life! What constitutes a negative conflict in Finland is a standard, the norm in Russia. (Respondent 2)

The interviewed immigrants had to adapt to the business principles of both Russia and Finland in terms of punctual behavior, which is an essential part of business ethics (Shaw, 1994). From the immigrants' perspective, attitudes toward punctuality differ in the two countries. Finland uses a stricter approach toward time, whereas Russians are less punctual due to a synchronic time orientation (Trompenaars and HampdenTurner, 2011), which implies that time commitments are desirable but not absolute. This reflects on business in the following ways:

In Russia, you need to confirm everything a few days before a meeting or trip. (Respondent 1)

In Finland, you go to a meeting at 10 a.m. and at 11 a.m. you're free, you know your schedule beforehand. In Russia, you can wait for half an hour in the lobby with no result. (Respondent 2 )

Punctual behavior has ethical implications, as it indicates a serious attitude on the part of a partner to the business at hand and is an indicator of respect. The non-punctual attitude of Russian partners leaves the interviewed entrepreneurs frequently feeling frustrated in dealing with the Russians. However, they realize it is common practice in Russia. Finnish managers practice punctuality to pay respect to business partners' time and personality. Thus, all the respondents claimed that it is easier to manage relationships with Finnish business partners in terms of appointments, deliveries, etc. 
Another aspect of business ethics that the respondents indicated as important is the hierarchy of power (Moberg, 1994; Vredenburgh and Brender, 1998). Respondent 2 clarified that everything is managed by one person [in Russia], even in a large company. Thereby, the interviewed entrepreneurs knew that if you need to order spare parts from a Russian partner, it is not enough to place an order with the officially responsible person. The order information needs to be communicated to the managerial staff and other related employees, as there is no guarantee that information will reach lower managerial levels from the top. Nevertheless, a strict hierarchy can have its benefits. Although managers in Finland make decisions based on discussions and consensus with all the involved actors, the Russian system runs to the contrary:

Because of authority power in Russia, decisions are made faster. (Respondent 1)

Despite certain benefits, dependency on one person raises the ethical issue of responsibility avoidance in lower managerial levels. According to the respondents and evidence from the literature, although the acceptance of responsibility for one's own actions is low in Russia (Rozov, 2011), managers in Finland at all levels, representing the Nordic managerial tradition (Asgary and Mitschow, 2002), take responsibility for the company's actions:

[In Russia] Nobody wants to take responsibility; nobody wants to be independent. They only want to take orders, and don't think about what they are doing. (Respondent 2)

The difference in power and hierarchy reflects the need for control over business processes. A high degree of control is typical for Russians, and remarkably, immigrant entrepreneurs apply these practices of control in their business in Finland out of habit.

\subsection{Ethical values in business relationships}

The respondents placed a special value on ethical qualities as the fulfillment of promises, considering the opinions of others in decision-making, professionalism and commitment, showing respect to people and their time, trust, transparency and responsibility. Similar values are expected of their employees.

Contrary to the view that friendship is important in Russian managers initiating business relationships (Ivanova and Torkkeli, 2013), the interviewees emphasized that friendship in business is unnecessary and even damaging to business relationships, which is in line with the research of Grayson (2007). Mixing friendship with business can serve as a base for blat (Ledeneva, 2009), which, in turn, may be regarded as unethical in certain countries:

In Russia, partners keep their distance. You can't talk about friendship in Russia. There's no feeling of brotherhood. (Respondent 1)

In Russia, a partner keeps their distance, irrespective of all acquaintances and good relationships. (Respondent 2 )

This interpretation of friendship concerning Russian business partners can also indicate that immigrants feel like outsiders in Russian business while also being outsiders, to some extent, in the Finnish business environment. Finnish managers' prejudices about Russians can prevent direct networking with Russian entrepreneurs residing in Finland. Prejudgment leads to some discrimination, here related to unethical behavior, implying evaluating a person based not on individual merits but some morally atrocious behavior (Velasquez, 2012). Russian immigrants experience this attitude in both countries:

In Russia, they told me that I'm not a Russian but a traitor. 'You left Russia, our country.' And in Finland it's something like 'What can you Russians make that doesn't break?' (Respondent 1)

It's better not to show that there are Russians in the company. (Respondent 3)

However, long-term business relationships with Russian partners can be beneficial in overcoming prejudices and being perceived as an insider, but as stated by the respondents, overly close relationships can lead to unethical behavior such as familiarity, meaning a partner being unceremonious or improper. The respondents referred to this behavior as unaccepted disrespect, which they all faced from Russian partners, saying that familiarity assumes breaking the rules of etiquette and attempting to communicate as closely-related people. Familiarity can be related to the hierarchy of power; that is one business partner attempts to demonstrate a dominant or equal position, exercising moral pressure on another partner (Anderson and Jap, 2005). While being a norm in Russia, this practice is not typical for Finns, as the principles of equality are embedded in Finnish business relationship management:

People in Russia switch to familiarity in relationships much faster than in Finland. Unfortunately, it's accepted there. (Respondent 1)

\subsection{Mutual learning of business ethics}

The respondents stressed that the majority of Russian managers still lack experience of business conduct in international markets. The interviewed entrepreneurs felt their mentoring role in teaching and guiding Russians about the international principles of business management. The immigrants disseminated knowledge of international ethical business behavior to Russian managers as well:

I just tell them how it's done in Finland, how we did it, how it happens, and I assure them they won't be punished for it. (Respondent 1)

The immigrant entrepreneurs also had to adapt to the different business motivations of Russians and Finns. Russians are more interested in making a prompt profit and acquiring short-term benefits (In Russia, they are only interested in making more money. Respondent 1), which may lead to corruption or some degree of opportunism (Hawkins et al., 2013). Finns are more inclined toward stability and steady development. From the Russian perspective, Finnish business is excessively traditional, conservative and slow in accepting new things.

Our Finnish partner said: 'We don't need to be rich. What we have is enough for us. My wife doesn't want the neighbors to be jealous.' (Respondent 4)

This traditionalism or acting as "everyone else," is rooted in the Finnish societal context (Siltaoja and Onkila, 2013). The respondents concluded that Finnish managers could learn from Russians to accept risk, creativity and being more active in the business. In turn, Russians should learn rationality and the ability to act with greater deliberation in making business decisions.

\section{Discussion}

The results indicate that the country of origin and experience of B2B relationships with partners from immigrants' home 
country can be both beneficial and create barriers to immigrants' adaptation to ethical values in their host country. The current study illustrates that despite these challenges, the interviewed managers managed to adapt and steer between the ethical norms of both countries, here by following the principle of ethical relativism. Managers develop their own adaptive ethical moral principles of business conduct based on the experiences of business relationships in both countries. The narratives demonstrate that immigrant entrepreneurs morally resist unethical business behavior and are keener to accept the Western style of business ethics. However, they are aware that some practices cannot be applied to international-level interactions when the case concerns business actors from emerging markets, who may lack international interaction experience or have to follow the local rules of the game.

Ironically, resistance to unethical business behavior can be destructive to partnerships in Russia, whereas it provides reputational gains in Finland. While in Finland the termination of an unethical business relationship is an act of risk avoidance, in Russia, such relationships can be the only way of doing business (Lewis, 2006). The turbulent environment forces Russian business partners to circumvent the law, to a reasonable extent; otherwise, businesses would not be able to operate in the Russian environment. Entrepreneurs from developed markets tend to use the minimum required moral norms in developing countries (Donaldson, 1989; Iyer, 2001). Immigrant entrepreneurs apply a similar approach and try to follow Western norms in the Russian business environment but leave some room for relativism.

In terms of adaptation, immigrants have better knowledge of the legal procedures in their country of origin. They are also aware of unethical practices they can face, in this case, in Russia. They do not expect complete honesty from Russian partners after signing contracts, which is controversial in terms of internationally accepted ethical principles (Asgary and Mitschow, 2002). However, they can trust Finns to honor a signed, solid contract. In turn, Finnish managers attempt to act ethically in their local market but can be more ethically flexible in business relationships with foreign-origin business partners. Emerging markets are not as regulated and, consequently, offer more business opportunities. Therefore, ethical relativism should be considered in the international environment (Thomas and Peterson, 2017).

The lack of adequate legal regulations leads to the issue of transparency in business activities. Transparency in business activities is typical in Nordic countries (Panapanaan et al., 2003) and can be a pledge of trust and commitment with business partners (Akkermans et al., 2004). The development of trust is significant if a business partner's promises cannot be supported with official documents (Myskja, 2008). Thus, in the case where actors cannot trust their foreign partners, contractual agreements may serve as a shield from dishonest actions and opportunistic behavior. However, contracts tend to have less weight in collectivistic countries (Handley and Angst, 2015), and Russia is one of those countries. Therefore, foreign business actors must rely on social networking and develop trust with Russian partners. While in Finland, according to the experiences of the respondents from the current study, contracts have solid weight and it is important to understand their content. Understanding contractual agreements may be difficult for foreigners who do not have proper knowledge of the Finnish language, which may open the way for local entrepreneurs to manipulate immigrant entrepreneurs.

Social interaction in the Russian market is frequently characterized by the strong presence of informal institutions and relationships, which are conceptualized as blat (Voldnes et al., 2012). Blat helps engage potential business partners in relationships and obtain connections with the "right" people, as well as to accelerate business processes. From the Finnish side, according to the respondents, a simple agreement or phone call may be enough to begin partnerships with new companies, depending on the complexity of the task. Social networking is significant in the Finnish market as well, but it aims at longterm business relationship development and risk avoidance due to the increased levels of loyalty and trust.

Russian immigrants have to deal with the challenges related to Finns' prejudices concerning Russian business actors. Prejudgment rests on stereotypes and frequently has negative connotations (Velasquez, 2012). The interviewed entrepreneurs attempted to overcome these prejudices by demonstrating the ethicality of their business activities and following the international ethical code of conduct. However, they have to deal with prejudices in both countries, not being completely accepted by either. Still, immigrants play a mentoring role for their business partners from their home country in communicating the Western-style (or Nordic in our case) of business conduct.

As adaptation is grounded in the differences among business partners (Gadde and Håkansson, 1993), immigrant entrepreneurs have to manage the ethical approach toward time. Russians may not always pay attention to the scheduled time of an appointment, but Finns are reliable in that sense. Punctuality shows respect to business partners and respect for their time and effort (Shaw, 1994). In general, productive business relationships are based on mutual respect (Edvardsson et al., 2014), which also originates in the morals and ethics of entrepreneurs. However, respect may be neglected if the relationships promptly move to a forced or unwelcomed friendship, which can be described as familiarity (Anderson and Jap, 2005). Familiarity is frequently counted as unethical and may cause tension between business partners. The respondents faced familiarity primarily with Russian business partners. This behavior has not ended their business relationships but brought some negative perceptions and attitudes toward social interaction.

Russians may show familiarity to business partners as a way to impose power, and the hierarchy of power is still visible in Russian business, which is not typical of Finns (Korhonen and Seppälä, 2005). However, the concentration of power settling within one person in an organization, which contradicts Finnish ethical norms (Asgary and Mitschow, 2002) but is practiced in Russia, can expedite decision-making processes. The immigrant entrepreneurs highlighted the importance of knowing who makes the final decision in a Russian business organization. Such reliance on one person may also be explained by responsibility avoidance by the lower-level managers (Rozov, 2011), especially if it concerns external business relationships, which was stressed by the respondents. Finnish entrepreneurs frequently consider the interests of all 
business partners and are keen to consider their perspectives in making business decisions.

Russian and Finnish managers frequently differ in their motivations for doing business. Although Finns appreciate stability and a long-term orientation, Russians are inclined to seek immediate profit generation by all possible (un)ethical means (Sidorov et al., 2000). The motivation of Finnish managers for aiming at long-term orientation can also be represented as a commitment to business relationships (Gounaris, 2005; Brown et al., 2019). Commitment does not always guarantee monetary benefits, but it can safeguard relationships from unexpected risks and bring moral satisfaction to the community (Høgevold et al., 2020). Commitment is frequently interrelated with loyalty, and loyalty in Russian markets can be strong in mature business relationships (Ivanova and Torkkeli, 2013) but lacking in new, recently established business relationships.

In general, Russian immigrant entrepreneurs play a mediating role in these processes, bridging two markets and managerial practices, thus acting as boundary spanners (Barner-Rasmussen et al., 2014). They manage to navigate between the ethical values of both countries, attempting to disseminate the best ethical practices but still considering ethical relativism. Table 3 summarizes the respondents' perceptions of the ethical specifics of doing business with Russian and Finnish business partners.

\section{Conclusions}

The ethical code of conduct in international business has to be grounded on universal principles and values rather than "domestic" values (Warren, 2011). Although the Global Compact initiative covers the main ethical issues regarding labor organizations, human rights and the environment, it is generally large multinationals that can afford to follow these rules. The managers of small businesses still have to rely on their own moral and ethical principles in managing international business relationships, especially in emerging markets. The current study has highlighted the issue of ethical relativism and the adaptation to ethical values that entrepreneurs have to undertake to establish successful international business relationships.
Adaptation to ethical values relates to the issue of ethical relativism, where there are no set ethical standards (Lovett et al., 1999). Although ethical relativism has been criticized for being a mere excuse for practicing unethical business (Donaldson, 1989), convergence toward Western ethical norms requires time and international experience from managers, which may still be lacking in emerging countries. Individuals may resist adaptation to foreign norms because of psychological barriers related to negative perceptions toward the country, region or organization from which these norms stem (Ivanova-Gongne, 2015). Contrarily, by adapting to the ethical norms of emerging countries, managers from developed countries can enter the market, thereby enabling interaction and knowledge transfer (e.g. of Western ethical norms).

The present study has examined Russian-origin immigrants who currently reside in Finland and are well aware of the norms of business ethics in both countries. These individuals know what to expect from a Finnish or Russian business partner and manage to adapt to the ethical specifics predominant in the two markets. These entrepreneurs are familiar with the meaning of blat and "roof" in the Russian market, as well as the possibility of Finnish managers acting less ethically in international markets and with foreigners. They attempt to oppose unethical practices in business partnerships and follow Nordic ethical principles such as honesty, transparency and commitment. They are aware of Russian specifics of power and hierarchy in business organizations, which does not necessarily have negative consequences. However, they realize that some unethical actions and corruption can be encountered during interactions between developed and emerging market representatives. Thus, immigrant entrepreneurs deliver knowledge on the best practices from developed to emerging markets with a low degree of experience of international interaction but still have to adapt to the local ethical principles for the sake of relationship development.

\subsection{Theoretical and managerial implications}

The current study contributes to the limited research on ethics in business marketing studies (Halinen and Jokela, 2016), providing insights into the ethical norms and values that can arise during international $\mathrm{B} 2 \mathrm{~B}$ interactions. The present study

Table 3 Ethical specifics of business conduct with Russian and Finnish business partners

\begin{tabular}{|c|c|c|}
\hline Relationships specifics & Finnish ethics & Russian ethics \\
\hline $\begin{array}{l}\text { Individual moral values } \\
\text { embedded in business } \\
\text { relationships }\end{array}$ & $\begin{array}{l}\text { Honesty, keeping promises, fairness, loyalty, the } \\
\text { pursuit of excellence. Familiarity is unacceptable }\end{array}$ & $\begin{array}{l}\text { Value of personal qualities over expertize or } \\
\text { professionalism; expressing familiarity as a tool in } \\
\text { long-term relationships }\end{array}$ \\
\hline $\begin{array}{l}\text { Ethicality of a business } \\
\text { partner }\end{array}$ & $\begin{array}{l}\text { Thinking not only about their own interests but } \\
\text { those of the whole network of partners }\end{array}$ & $\begin{array}{l}\text { Low interest in benefits for the network of business } \\
\text { partners, opportunistic behavior }\end{array}$ \\
\hline Developing trust & $\begin{array}{l}\text { Transparency and openness in local networks but } \\
\text { suspiciousness where partners in international } \\
\text { (especially emerging) markets are concerned }\end{array}$ & Low trust in business partners \\
\hline Power and hierarchy & $\begin{array}{l}\text { Discussion with and listening to partners; decisions } \\
\text { are made to benefit all involved actors. Problems } \\
\text { caused by a company are solved collectively within } \\
\text { the company }\end{array}$ & $\begin{array}{l}\text { Management depends on key persons in a company, } \\
\text { which can slow the interaction process. One person } \\
\text { is blamed for the company's failure }\end{array}$ \\
\hline Attitude and respect & $\begin{array}{l}\text { Commitment and equal respect shown to all } \\
\text { business partners }\end{array}$ & $\begin{array}{l}\text { Unintentional disrespect of the partner's time or } \\
\text { personality }\end{array}$ \\
\hline
\end{tabular}


illustrates the importance of ethical norms embedded in international relationship management (Lindfelt and Törnroos, 2006) and approaches business ethics from the perspective of relativism (McDonald, 2010), implying that ethics are relative to a certain business context. By illustrating immigrant entrepreneurs' understanding of ethical values, the current study also contributes to international entrepreneurship research, which has predominantly focused on the cultural and social embeddedness of immigrants and largely ignored its ethical aspects (for rare exceptions, Azmat, 2010; Fatoki, 2015).

The current paper has discussed the challenges of adaptation (Brennan et al., 2003) to ethical norms that immigrant entrepreneurs face in international markets, adding to the literature on country-specific business ethics (Asgary and Mitschow, 2002). Although there is extensive literature on Russian business ethics (Ledeneva, 2009; Michailova and Worm, 2003), it is primarily dedicated to the turbulent economic times of the 1990s. Our results showcase the lack of radical change in ethical practices in Russian business since then, even though they are increasingly oriented to the Western premises of the ethical business. Academic research on Finnish business ethics is discussed in a limited range of literature that represents it as a part of the Western or Nordic business ethics tradition. Thereby, our study extends knowledge on Finnish business ethics. Finally, by examining business ethics from the perspective of relativism, our study contributes to the longstanding discussion in international business on the need to contextualize research (Michailova, 2011).

The main managerial implication is that ethical norms and values are crucial in managing international business relationships and networks. Managers should acquire knowledge on ethical norms not only at the global level but also at the national level, depending on where they aim to expand their business. Our findings contribute to the understanding of how ethical interaction among international B2B actors is facilitated according to the context of the relationships, avoiding anecdotal situations and enabling adaptation to international business realities. According to the present study, productive international business relationships often involve the premises of honesty, transparency, treating business partners fairly and minimizing opportunism. Business relations between developed and emerging markets may demand relativism in addressing ethical behavior. For instance, some company representatives (especially in emerging markets) may avoid responsibilities and demonstrate personal behavior that could be considered disrespectful to their business partner. A norm of behavior in one business environment can be unacceptable in another country, such as the familiarity frequently displayed by Russian business partners. Adaptation may be required regarding the perceptions of time in different cultures and to the fact that some international business actors value their partners' personal over professional qualities.

\subsection{Limitations and future studies}

Although business ethics and culture are closely interconnected, an in-depth focus on culture was intentionally omitted in the current study. The research was narrowed to the investigation of business ethics in international business relationships and networks. Despite the current study's contributions to the cross-cultural literature on business ethics, further studies should provide more insights into the role of culture in the behavior of immigrants in international business relationships. Research on immigrants with different levels of cultural integration requires more empirical studies, especially in times of increased workforce immigration.

The selection of the respondents for data collection is not extensive in the current study, as there is a limited number of entrepreneurs in Finland fulfilling all of our inclusion criteria. Russian immigrant entrepreneurs might not always have experience of $\mathrm{B} 2 \mathrm{~B}$ relationships with Russian business partners and primarily operate in the local Finnish market or other markets within the EU. Further empirical research is needed to gain more knowledge on the adoption of ethical values by immigrant entrepreneurs doing business with partners from both the host and home (country of origin) markets.

\section{References}

Akkermans, H., Bogerd, P. and Van Doremalen, J. (2004), "Travail, transparency and trust: a case study of computersupported collaborative supply chain planning in high-tech electronics", European fournal of Operational Research, Vol. 153 No. 2, pp. 445-456.

Anderson, E. and Jap, S.D. (2005), "The dark side of close relationships”, MIT Sloan Management Review, Vol. 46 No. 3, pp. 75-83.

Apressyan, R.G. (1997), "Business ethics in Russia", Fournal of Business Ethics, Vol. 16 No. 14, pp. 1561-1570.

Arnott, D.C. (2007), "Trust - current thinking and future research", European fournal of Marketing, Vol. 41 Nos 9/10, pp. 981-987.

Asgary, N. and Mitschow, M.C. (2002), "Toward a model for international business ethics", Fournal of Business Ethics, Vol. 36 No. 3, pp. 239-246.

Azmat, F. (2010), "Exploring social responsibility of immigrant entrepreneurs: do home country contextual factors play a role?", European Management fournal, Vol. 28 No. 5, pp. 377-386.

Bailey, W. and Spicer, A. (2007), "When does national identity matter? Convergence and divergence in international business ethics", Academy of Management fournal, Vol. 50 No. 6, pp. 1462-1480.

Banalieva, E.R., Puffer, S.M., McCarthy, D.J. and Vaiman, V. (2018), "The impact of communist imprint prevalence on the risk-taking propensity of successful Russian entrepreneurs", European f. Of International Management, Vol. 12 Nos 1/2, pp. 158-190.

Barner-Rasmussen, W., Ehrnrooth, M., Koveshnikov, A. and Mäkelä, K. (2014), "Cultural and language skills as resources for boundary spanning within the MNC", fournal of International Business Studies, Vol. 45 No. 7, pp. 886-905.

Beekun, R.I., Stedham, Y., Yamamura, J.H. and Barghouti, J. A. (2003), "Comparing business ethics in Russia and the US", The International fournal of Human Resource Management, Vol. 14 No. 8, pp. 1333-1349.

Boatright, J.R. (2000), "Globalization and the ethics of business", Business Ethics Quarterly, Vol. 10 No. 1, pp. 1-6.

Boje, D.M. (2001), Narrative Methods for Organizational and Communication Research, Sage Publications, London. 
Brennan, D.R. and Turnbull, P.W. (1996), "The process of adaptation in interfirm relationships", Proceedings of the 12th IMP conference, University of Karlsruhe, Karlsruhe, pp. 127-148.

Brennan, D.R., Turnbull, P.W. and Wilson, D.T. (2003), "Dyadic adaptation in business-to-business markets", European fournal of Marketing, Vol. 37 Nos 11/12, pp. 1636-1665.

Brinkmann, J. (2002), "Business and marketing ethics as professional ethics. Concepts, approaches and typologies”, Fournal of Business Ethics, Vol. 41 Nos 1/2, pp. 159-177.

Brown, J.R., Crosno, J.L. and Tong, P.Y. (2019), "Is the theory of trust and commitment in marketing relationships incomplete?", Industrial Marketing Management, Vol. 77, pp. 155-169.

Chen, S.X., Benet-Martínez, V. and Harris Bond, M. (2008), "Bicultural identity, bilingualism, and psychological adjustment in multicultural societies: immigration-based and globalization-based acculturation", fournal of Personality, Vol. 76 No. 4, pp. 803-838.

Cory, J. (2005), Activist Business Ethics, Springer, New York, NY.

De George, R.T. (1993), Competing with Integrity in International Business, Oxford University Press, New York, NY.

Devitt, C. (2011), "Varieties of capitalism, variation in labour immigration", fournal of Ethnic and Migration Studies, Vol. 37 No. 4, pp. 579-596.

Dion, M. (2010), "Corruption and ethical relativism: what is at stake?”, fournal of Financial Crime, Vol. 17 No. 2, pp. 240-250.

Dobrucali, B. (2019), "The role of Guanxi on international business-to-business relationships: a systematic review and future directions", fournal of Business and Industrial Marketing, Vol. 33 No. 7, pp. 1125-1140.

Donaldson, T. (1989), The Ethics of International Business, Oxford University Press, Oxford.

Edvardsson, B., Kowalkowski, C., Strandvik, T. and Voima, P. (2014), "Negative critical waves in business relationships: an extension of the critical incident perspective", Fournal of Business E Industrial Marketing, Vol. 29 No. 4, pp. 284-294.

Elliott, J. (2005), Using Narrative in Social Research: Qualitative and Quantitative Approaches, Sage, London.

Fatoki, O. (2015), "An investigation into the ethical ideology of immigrant entrepreneurs in South Africa", Fournal of Social Sciences, Vol. 43 No. 2, pp. 91-96.

Fiske, S.T. (2005), "Social cognition and the normality of prejudgment", in Dovidio, J.F., Glick, P. and Rudman, L.A. (Eds), On the Nature of Prejudgment: fifty Years after Allport, Blackwell Publishing, Oxford, pp. 36-49.

Fornaro, P. (2018), "Immigrant entrepreneurship in Finland", ETLA Report No 83, available at: https://pub.etla.fi/ETLARaportit-Reports-83.pdf

Gadde, L.E. and Håkansson, H. (1993), Professional Purchasing, Routledge, London.

Gounaris, S.P. (2005), "Trust and commitment influences on customer retention: insights from business-to-business services", Fournal of Business Research, Vol. 58 No. 2, pp. 126-140.
Grayson, K. (2007), "Friendship versus business in marketing relationships", Fournal of Marketing, Vol. 71 No. 4, pp. 121-139.

GrcIc", J. (1989), Moral Choices: Ethical Theories and Problems, West Publishing, US.

Grennes, T. (2011), "Will the 'Scandinavian leadership model' survive the forces of globalization? A SWOT analysis", International fournal of Business and Globalization, Vol. 7 No. 3, pp. 332-350.

Gurău, C., Dana, L.P. and Katz-Volovelsky, E. (2020), "Spanning transnational boundaries in industrial markets: a study of Israeli entrepreneurs in China", Industrial Marketing Management, Vol. 89.

Hagberg-Andersson, Å. (2006), "Does adaptation pay off?", Industrial Marketing Management, Vol. 35 No. 2, pp. 202-209.

Halinen, A. and Törnroos, J. (1998), "The role of embeddedness in the evolution of business networks", Scandinavian Fournal of Management, Vol. 14 No. 3, pp. 187-205.

Halinen, A. and Jokela, P. (2016), "Exploring ethics in business networks: propositions for future research", in Thilenius, P., Pahlberg, C. and Havila, V. (Eds), Extending the Business Network Approach - New Territories, New Technologies, New Terms, Palgrave Macmillan, London, pp. 333-356.

Handley, S.M. and Angst, C.M. (2015), "The impact of culture on the relationship between governance and opportunism in outsourcing relationships", Strategic Management fournal, Vol. 36 No. 9, pp. 1412-1434.

Hawkins, T.G., Pohlen, T.L. and Prybutok, V.R. (2013), "Buyer opportunism in business-to-business exchange", Industrial Marketing Management, Vol. 42 No. 8, pp. 1266-1278.

Hisrich, R.D., Bucar, B. and Oztark, S. (2003), "A crosscultural comparison of business ethics: cases of Russia, Slovenia, Turkey, and United States", Cross Cultural Management: An International fournal, Vol. 10 No. 1, pp. 3-28.

Høgevold, N., Svensson, G. and Otero-Neira, C. (2020), "Trust and commitment as mediators between economic and non-economic satisfaction in business relationships: a sales perspective", Fournal of Business E Industrial Marketing, Vol. 35 No. 11, pp. 1685-1700.

Holmlund, M. and Törnroos, J. (1997), "What are relationships in business networks?", Management Decision, Vol. 35 No. 4, pp. 304-309.

Holzlehner, T. (2007), "The harder the rain, the tighter the roof' evolution of organized crime networks in the Russian far east", Sibirica, Vol. 6 No. 2, pp. 51-86.

Hrenyk, J., Szymanski, M., Kar, A. and Fitzsimmons, S.R. (2016), "Understanding multicultural individuals as ethical global leaders", Advances in Global Leadership, Vol. 9, pp. 57-78.

Ivanova, M. and Torkkeli, L. (2013), "Managerial sensemaking of interaction within business relationships: a cultural perspective", European Management fournal, Vol. 31 No. 6, pp. 717-727.

Ivanova-Gongne, M. (2015), "Culture in business relationship interaction: an individual perspective", Fournal of Business $\mathcal{E}$ Industrial Marketing, Vol. 30 No. 5, pp. 608-615. 
Ivanova-Gongne, M. and Torkkeli, L. (2018), "No manager is an island: culture in sensemaking of business networking", Fournal of Business \& Industrial Marketing, Vol. 33 No. 5, pp. 638-650.

Iyer, G.R. (2001), "International exchanges as the basis for conceptualizing ethics in international business", fournal of Business Ethics, Vol. 31 No. 1, pp. 3-24.

Jansson, H. International Business Marketing in Emerging Country Markets: The Third Wave of Internationalization of Firms, Edward Elgar, Cheltenham.

Jansson, H.A., Johanson, M. and Ramström, J. (2007), "Institutions and networks: business networks in the Chinese, Russian, and West-European institutional contexts", Industrial Marketing Management, Vol. 36 No. 7, pp. 955-967.

Javalgi, R.G. and Russell, L.T.M. (2018), "International marketing ethics: a literature review and research agenda", Fournal of Business Ethics, Vol. 148 No. 4, pp. 703-720.

Karhunen, P., Kosonen, R., McCarthy, D.J. and Puffer, S.M. (2018), "The darker side of social networks in transforming economies: corrupt exchange in Chinese Guanxi and Russian Blat/Svyazi”, Management and Organization Review, Vol. 14 No. 2, pp. 395-419.

Korhonen, J. and Seppälä, N. (2005), "The strength of a hightrust society", in Habisch, A., Jonker, J., Wegner, M., Schmidpeter, R. (Eds), Corporate Social Responsibility across Europe, Springer, Berlin. pp. 3-22.

Kujala, J. (2004), "Manager's moral perceptions: change in Finland during 1990s", Business Ethics: a European Review, Vol. 13 Nos 2/3, pp. 143-165.

Kvale, S. (1996), Interviews: An Introduction to Qualitative Research Writing, Sage Publications, Thousand Oaks, CA.

Labov, W. and Waletzky, J. (1967), "Narrative analysis: oral versions of personal experience", in Helm, J. (Ed.), Essays on the Verbal and Visual Arts, University of Washington, DC Press, Seattle, pp. 12-44.

Ledeneva, A. (2009), "From Russia with Blat: can informal networks help modernize Russia?”, fournal of Social Research, Vol. 76 No. 1, pp. 257-288.

Lewis, R.D. (2006), When Cultures Collide: leading across Cultures, 3rd ed., Nickolas Brealey International, London.

Lindfelt, L.-L. and Törnroos, J. (2006), "Ethics and value creation in business research: comparing two approaches", European fournal of Marketing, Vol. 40 Nos 3/4, pp. 328-351.

Lovett, S., Simmons, L.C. and Kali, R. (1999), "Guanxi versus the market: ethics and efficiency", fournal of International Business Studies, Vol. 30 No. 2, pp. 231-247.

Lukes, S. (2008), Moral Relativism, Picador, New York, NY.

McCarthy, D. and Puffer, S. (2002), "Corporate governance in Russia: towards a European, US, or Russian model?”, European Management fournal, Vol. 20 No. 6, pp. 630-640.

Mccarthy, D.J. and Puffer, S.M. (2008), "Interpreting the ethicality of corporate governance decisions in Russia: utilizing integrative social contracts theory to evaluate the relevance of agency theory norms", Academy of Management Review, Vol. 33 No. 1, pp. 11-31.

McDonald, G. (2010), "Ethical relativism vs absolutism: research implications", European Business Review, Vol. 22 No. 4, pp. 446-464.
Makkonen, H., Aarikka-Stenroos, L. and Olkkonen, R. (2012), "Narrative approach in business network process research implications for theory and methodology", Industrial Marketing Management, Vol. 41 No. 2, pp. 287-299.

Melé, D. (2009), "The practice of networking: an ethical approach", Fournal of Business Ethics, Vol. 90, pp. 487-503.

Michailova, S. (2011), "Contextualizing in international business research: why do we need more of it and how can we be better at it?", Scandinavian fournal of Management, Vol. 27 No. 1, pp. 129-139.

Michailova, S. and Worm, V. (2003), "Personal networking in Russia and China: Blat and Guanxi”, European Management fournal, Vol. 21 No. 4, pp. 509-519.

Milanesi, M., Guercini, S. and Waluszewski, A. (2016), “A Black Swan in the district? An IMP perspective on immigrant entrepreneurship and changes in industrial districts", IMP Fournal, Vol. 10 No. 2, pp. 243-259.

Miller, R.J., Munoz, L. and Mallin, M. (2020), "Acquaintances or friends? Exploring the effects of contracts, trust and ethical level on opportunism in manufacturerdistributor relationships", fournal of Business and Industrial Marketing.

Moberg, D.J. (1994), "An ethical analysis of hierarchical relations in organizations", Business Ethics Quarterly, Vol. 4 No. 2, pp. 205-220.

Mora Cortez, R. and Johnston, W.J. (2019), "Marketing role in B2B settings: evidence from advanced, emerging and developing markets", fournal of Business $\mathcal{E}$ Industrial Marketing, Vol. 34 No. 3, pp. 605-617.

Morrison, J. (2015), Business Ethics: New Challenges in a Globalised World, Macmillan International Higher Education, London.

Myskja, B.K. (2008), "The categorical imperative and the ethics of trust", Ethics and Information Technology, Vol. 10, pp. 213-220.

Nazareno, J., Zhou, M. and You, T. (2019), "Global dynamics of immigrant entrepreneurship: changing trends, ethnonational variations, and reconceptualizations", International Fournal of Entrepreneurial Behavior \& Research, Vol. 25 No. 5, pp. 780-800.

Oumlil, A.B. and Balloun, J.L. (2017), "Cultural variations and ethical business decision making: a study of individualistic and collective culture", fournal of Business $\mathcal{G}$ Industrial Marketing, Vol. 32 No. 7, pp. 889-900.

Palazzo, G., Krings, F. and Hoffrage, U. (2012), "Ethical blindness", fournal of Business Ethics, Vol. 109 No. 3, pp. 323-338.

Panapanaan, V.M., Linnanen, L., Karvonen, M.-M. and Phan, V.T. (2003), "Roadmapping corporate social responsibility in Finnish companies", fournal of Business Ethics, Vol. 44 Nos 2/3, pp. 133-148.

Puffer, S.M. and McCarthy, D.J. (2011), "Two decades of Russian business and management research: an institutional theory perspective", Academy of Management Perspectives, Vol. 25 No. 2, pp. 21-36.

Riessman, C.K. (2005), "Narrative analysis", in Kelly, N., Horrocks, C., Milnes, K., Roberts, B. and Robinson, D. (Eds), Narrative, Memory $\mathcal{E}$ Everyday Life, University of Huddersfield, Huddersfield, pp. 1-7. 
Rozov, N. (2011), "Russian mentality: the most constructive concepts and their critiques", Mir Rossii, Vol. 2, pp. 100-113.

Shaw, J. (1994), "Punctuality and the everyday ethics of time: some evidence from the mass observation archive", Time $\mathcal{E}$ Society, Vol. 3 No. 1, pp. 79-97.

Sidorov, A., Alexeyeva, I. and Shklyarik, E. (2000), "The ethical environment of Russian business", Business Ethics Quarterly, Vol. 10 No. 4, pp. 911-924.

Siltaoja, M.E. and Onkila, T.J. (2013), "Business in society or business and society: the construction of business-society relations in responsibility reports form a critical discursive perspective", Business Ethics: A European Review, Vol. 22 No. 4, pp. 357-373.

Statistics Finland (2018), "Immigration and emigration by country of exit/entry, sex and country of birth 1990-2016", available at: http://pxnet2.stat.fi/PXWeb/pxweb/en/ Maahanmuuttajat_ja_kotoutuminen/Maahanmuuttajat_ja_ kotoutuminen_Maahanmuuttajat_ja_kotoutuminen/?tablelist= true

Strand, R., Freeman, R.E. and Hockerts, K. (2015), "Corporate social responsibility and sustainability in Scandinavia: an overview", fournal of Business Ethics, Vol. 127 No. 1, pp. 1-15.

Thomas, D.C. and Peterson, M.F. (2017), Cross-Cultural Management: Essential Concepts, Sage Publications, Thousand Oaks, CA.

Trompenaars, F. and Hampden-Turner, C. (2011), Riding the Waves of Culture: Understanding Diversity in Global Business, Nicholas Brealey International, London. van Zeeland-van der Holst, E.M. and Henseler, J. (2018), "Thinking outside the box: a neuroscientific perspective on trust in B2B relationships", IMP fournal, Vol. 12 No. 1, pp. 75-110.

Velasquez, M.G. (2012), Business Ethics: Concepts and Cases, 7th ed., Pearson, London.

Voldnes, G., Grønhaug, K. and Nilssen, F. (2012), "Satisfaction in buyer-seller relationships - influence of cultural differences", Industrial Marketing Management, Vol. 41 No. 7, pp. 1081-1093.

Vredenburgh, D. and Brender, Y. (1998), "The hierarchical abuse of power in work organizations", fournal of Business Ethics, Vol. 17 No. 12, pp. 1337-1347.

Warren, R.C. (2011), "Are we making progress in international business ethics?", Humanomics, Vol. 27 No. 3, pp. 212-224.

Weiss, R.S. (2008), Learning from Strangers: The Art and Method of Qualitative Interview Studies, eFree Press, New York, NY.

Welch, C. and Piekkari, R. (2006), "Crossing language boundaries: qualitative interviewing in international business", Management International Review, Vol. 46 No. 4, pp. 417-437.

Zolfagharian, M. and Iyer, P. (2020), "The effects of intergroup boundary permeability and hierarchy legitimacy on immigrant entrepreneurs' affective states, exchange strategies, and intentions toward suppliers", Industrial Marketing Management, Vol. 89, pp. 373-388.

\section{Corresponding author}

Olga Dziubaniuk can be contacted at: odziuban@abo.fi 